\title{
Heritabilities of measured and mid-infrared predicted milk fat globule size, milk fat and protein percentages, and their genetic correlations
}

\author{
A. Fleming, ${ }^{* 1}$ F. S. Schenkel, ${ }^{*}$ A. Koeck, ${ }^{*}$ F. Malchiodi, ${ }^{*}$ R. A. Ali,† M. Corredig,ł B. Mallard, $§$ M. Sargolzaei, ${ }^{*}$ \\ and F. Miglior*II \\ ${ }^{*}$ Centre for Genetic Improvement of Livestock, Department of Animal Biosciences, \\ †Department of Mathematics and Statistics, \\ ‡Department of Food Science, and \\ §Department of Pathobiology, University of Guelph, Guelph, ON, N1G 2W1, Canada \\ \#Semex Alliance, Guelph, ON, N1H 6J2, Canada \\ IICanadian Dairy Network, Guelph, ON, N1K 1E5, Canada
}

\section{ABSTRACT}

The objective of this study was to estimate the heritability of milk fat globule (MFG) size and mid-infrared (MIR) predicted MFG size in Holstein cattle. The genetic correlations between measured and predicted MFG size with milk fat and protein percentage were also investigated. Average MFG size was measured in 1,583 milk samples taken from 254 Holstein cows from 29 herds across Canada. Size was expressed as volume moment mean $(\mathrm{D}[4,3])$ and surface moment mean $(\mathrm{D}[3,2])$. Analyzed milk samples also had average MFG size predicted from their MIR spectral records. Fat and protein percentages were obtained for all test-day milk samples in the cow's lactation. Univariate and bivariate repeatability animal models were used to estimate heritability and genetic correlations. Moderate heritabilities of 0.364 and 0.466 were found for $\mathrm{D}[4,3]$ and $\mathrm{D}[3,2]$, respectively, and a strong genetic correlation was found between the 2 traits (0.98). The heritabilities for the MIR-predicted MFG size were lower than those estimated for the measured MFG size at 0.300 for predicted $\mathrm{D}[4,3]$ and 0.239 for predicted $\mathrm{D}[3,2]$. The genetic correlation between measured and predicted $\mathrm{D}[4,3]$ was 0.685 ; the correlation was slightly higher between measured and predicted $\mathrm{D}[3,2]$ at 0.764 , likely due to the better prediction accuracy of $\mathrm{D}[3,2]$. Milk fat percentage had moderate genetic correlations with both $\mathrm{D}[4,3]$ and $\mathrm{D}[3,2]$ (0.538 and 0.681 , respectively). The genetic correlation between predicted MFG size and fat percentage was much stronger (greater than 0.97 for both predicted $\mathrm{D}[4,3]$ and $\mathrm{D}[3,2])$. The stronger correlation suggests a limitation for the use of the predicted values of MFG size as indicator traits for true

Received November 1, 2016.

Accepted January 21, 2017.

${ }^{1}$ Corresponding author: fleminga@uoguelph.ca average MFG size in milk in selection programs. Larger samples sizes are required to provide better evidence of the estimated genetic parameters. A genetic component appears to exist for the average MFG size in bovine milk, and the variation could be exploited in selection programs.

Key words: milk fat globule, mid-infrared prediction, genetic parameter

\section{INTRODUCTION}

Fat is an important component of milk because it has a role in the economic value, nutrition, and technological properties of milk and milk products. More than $95 \%$ of the total fat in milk is present in the form of milk fat globules (MFG; Keenan and Dylewski, 1995), a triple layer cellular membrane surrounding a globule of primarily triacylglycerol. Walstra (1969) reported that MFG with a diameter of less than $1 \mu \mathrm{m}$ represented $80 \%$ of all MFG, but only $5 \%$ of milk fat volume, while MFG ranging from 1 to $8 \mu \mathrm{m}$ comprised approximately $94 \%$ of fat. The remaining 1 to $2 \%$ of the fat volume comes from a small number of large MFG with a diameter greater than $8 \mu \mathrm{m}$. Milk fat globule triacylglycerols are synthesized at the rough endoplasmic reticulum, accumulated, and then released as microlipid droplets into the cytosol with a surface coat of polar lipids and proteins derived from the endoplasmic reticulum and the mammary cell (Mather and Keenan, 1998). The droplets grow in size through coalescence with each other as they migrate from their sites of origin to the apical region, where growth is most pronounced (Stemberger and Patton, 1981). The mechanisms involved in the fusion of lipid droplets and whether these processes are regulated or random remain speculative. The average size of MFG can be affected by multiple factors including breed (Carroll et al., 2006), stage of lactation (Walstra, 1995), and 
diet (Wiking et al., 2003). Variation in MFG diameter between individual animals within a herd was reported by Logan et al. (2014), which suggests potential genetic differences for MFG size and the possibility of selecting cows for this trait.

Milk fat globule size is a trait of interest because it affects the technological and sensory properties and nutritional quality of milk and milk products (Martini et al., 2016). Milk fat globules affect the stability of the emulsions, the creaming rate, and the crystallization of milk fat (Huppertz and Kelly, 2006). Michalski et al. (2003) showed that using milk with either small or large MFG could alter the moisture content and texture of cheese. Of interest to consumers are the health benefits of many of the MFG membrane components, which include important minor lipids and glycoproteins (Spitsberg, 2005). The addition of MFG membrane to the diet of infants and children has been shown to have possible positive benefits for neurodevelopment and defense against infections (Hernell et al., 2016). At a given amount of fat, cows producing small MFG will be producing higher amounts of the beneficial MFG membrane material.

Mid-infrared (MIR) spectroscopy has been used to quantify fat and protein content in milk samples in dairy herd improvement for decades. The use of this technology has more recently expanded to predict additional milk components and properties, including fatty acid content (Rutten et al., 2009; Soyeurt et al., 2011), protein composition (Bonfatti et al., 2011), mineral content (Soyeurt et al., 2009), and milk coagulation properties (Cecchinato et al., 2009). In the context of cow physiology, MIR spectroscopy has been used to assess energy intake and efficiency (McParland et al., 2014). The MIR-predicted values could act as indicator traits to allow for the routine genetic evaluation of many meaningful traits for which large-scale phenotyping would otherwise be unattainable. Most importantly, MIR spectroscopy is already used in milk recording programs, and this system could be used to predict additional, novel traits with minimal added infrastructure. The adequacy of MIR predicted traits for selection purposes depends on the performance of the prediction equation. Knowledge of the genetic correlations between the predicted values, their true values, and other milk components could give insight into their utility in breeding programs.

Few studies have investigated the genetic influence on MFG size and the corresponding estimated genetic parameters. The objective of this study was to estimate genetic parameters of measured and MIR-predicted average MFG size and their genetic correlations with each other and with milk fat and protein percentages.

\section{MATERIALS AND METHODS}

\section{Data}

Individual cow milk samples were obtained from 254 Holstein cows from 29 participating herds between March 2013 and April 2015. Approximately 10 cows per participating herd were preselected, with half being at the beginning of their lactation and half at mid lactation. Milk was collected as a part of routine milk recording programs by trained field staff from Canadian DHI partners, CanWest DHI (Guelph, ON, Canada) and Valacta (Ste-Anne-de-Bellevue, QC, Canada). Sampling occurred multiple times throughout the project time frame, with the time of day of milking alternating with each DHI milk collection visit. The average number of milk samples per cow was 6.3 and ranged from 1 to 14 . In total, 246 cows had more than one milk sample, and 123 of these cows had milk samples coming from a second lactation. In total, 1,589 milk samples were analyzed for average MFG size.

Milk fat globule size distribution was measured on fresh (never frozen) milk samples by integrated light scattering with a Malvern Mastersizer 2000 (Southborough, MA) using a 2-wavelength protocol. Immediately before measurement, samples were diluted 1:1 in 80 $\mathrm{m} M$ EDTA/NaOH solution ( $\mathrm{pH} 7$ ) to minimize the signal from the casein micelles by adding $1 \mathrm{~mL}$ of EDTA buffer to $1 \mathrm{~mL}$ of milk and vortexing. The absorption coefficients of liquid milk fat used for measurement were $0.5 \times 10^{-5}$ and $1.7 \times 10^{-5}$ at 633 and $466 \mathrm{~nm}$, respectively. The refractive indices of MFG in water were 1.458 and 1.460 at 633 and $466 \mathrm{~nm}$, respectively. Whole milk was measured at 2,800-rpm speed stirring. The obscuration was 10 to $15 \%$. The mean diameter of the MFG was calculated by the integrated software and expressed as volume moment mean $(\mathbf{D}[\mathbf{4 , 3}])$ and surface moment mean $(\mathbf{D}[\mathbf{3}, \mathbf{2}])$ defined by the equation:

$$
\mathrm{D}[k, z]=\frac{\sum N_{i} d_{i}^{k}}{\sum N_{i} d_{i}^{z}},
$$

where $N_{i}$ is the number of globules in a size class of $d_{i}$.

If $\mathrm{D}[4,3]$ was lower than $\mathrm{D}[3,2]$, a recording error was assumed and the corresponding records were omitted. Records for which $\mathrm{D}[4,3]$ or $\mathrm{D}[3,2]$ were farther than 4 standard deviations away from the mean were also removed. After edits, 1,583 milk samples had $\mathrm{D}[4,3]$ and 1,586 had $\mathrm{D}[3,2]$ data.

Predicted $\mathrm{D}[4,3](\mathbf{p D}[\mathbf{4 , 3}])$ and predicted $\mathrm{D}[3,2]$ $(\mathrm{pD}[3,2])$ were obtained for these data from the saved MIR spectra of the milk samples and the calibration 
equations previously described by Fleming et al. (2017). The MIR prediction equations were developed to predict average MFG size in milk samples using a multibreed calibration set that included the Holstein samples used in the present study. The coefficients of determination of cross validation $\left(\mathrm{R}_{\mathrm{cv}}^{2}\right)$ of the prediction equations were 0.51 and 0.54 for $\mathrm{D}[4,3]$ and $\mathrm{D}[3,2]$, respectively (Fleming et al., 2017). As a result of some milk samples not having recorded MIR spectra or having spectra deemed to be outliers, 1,551 samples had $\mathrm{pD}[3,2]$ and 1,549 had $\mathrm{pD}[3,2]$.

Test-day fat and protein percentages determined during milk recording procedures were obtained from the Canadian Dairy Network (Guelph, ON, Canada). If one test-day in a cow's lactation had MFG size recorded, the fat and protein percentage for all test days in that lactation were kept. As a result, 3,643 fat and protein percentage records were kept for these traits (average of 14.5 samples per cow). A full pedigree going back as many generations as available containing 22,819 individuals was provided by the Canadian Dairy Network. The 254 cows with records were the progeny of 169 different sires.

\section{Genetic Analysis}

Univariate and bivariate repeatability animal models were used to analyze the data. The genetic correlation between the repeated measurements was assumed to be 1 across the lactation and parities. Variance components were estimated using the average information-REML (AI-REML) procedure in the DMU package (Madsen and Jensen, 2008). The following linear animal model was applied to all traits:

$$
y_{i j k l m n}=\mu+H S_{i}+P_{j}+D I M_{k}+p e_{l}+a_{m}+e_{i j k l m n},
$$

where $y_{i j l k m n}$ is the dependent $\mathrm{D}[4,3], \mathrm{D}[3,2], \mathrm{pD}[4,3]$, $\mathrm{pD}[3,2]$, fat percentage, or protein percentage; $\mu$ is the overall mean; $H S_{i}$ is the fixed herd season effect $(i=$ $1-114) ; P_{j}$ is the fixed effect of parity $(j=1$ to 4 and more); $D I M_{k}$ is the fixed effect of days in milk class ( $k$ $=1-11$; class 1: 5-30 d, class 2: 31-60 d, class 3: 61-90 $\mathrm{d}, \ldots$, class 10: 271-305 d, and class 11: >305 d after calving); $p e_{l}$ is the random permanent environment effect $(l=1-254) ; a_{m}$ is the random additive genetic effect of the animal ( $m=1-22,819)$; and $e_{i j k l m n}$ is the random error term.

Heritability was calculated using variance components estimated from the univariate analysis of each trait as $\sigma_{a}^{2} /\left(\sigma_{a}^{2}+\sigma_{p e}^{2}+\sigma_{e}^{2}\right)$, where $\sigma_{a}^{2}$ is the additive genetic variance, $\sigma_{p e}^{2}$ is the permanent environmental variance, and $\sigma_{e}^{2}$ is the residual variance. Repeatability was defined as $\left(\sigma_{a}^{2}+\sigma_{p e}^{2}\right) /\left(\sigma_{a}^{2}+\sigma_{p e}^{2}+\sigma_{e}^{2}\right)$. Genetic correlations between traits were estimated from the series of 14 bivariate analyses with $\mathrm{D}[4,3], \mathrm{D}[3,2], \mathrm{pD}[4,3]$, and $\mathrm{pD}[3,2]$ among themselves and with fat and protein percentages.

\section{RESULTS AND DISCUSSION}

\section{Descriptive Statistics}

Descriptive statistics for all examined traits in the edited data set are displayed in Table 1 . The mean $\mathrm{D}[4,3]$ was $4.130 \pm 0.483 \mu \mathrm{m}$, whereas $\mathrm{D}[3,2]$ had a lower mean of $3.468 \pm 0.339 \mu \mathrm{m}$. These values are within the range reported by Huppertz and Kelly (2006) and Martini et al. (2016). The MIR predicted values for these traits had similar means to the measured MFG, but the variation observed in the predicted traits was lower. This phenomenon is a consequence of the low predictive power of the model whereby values in the extreme parts of the distribution (i.e., in the tails) are predicted to be closer to the mean than their corresponding true measured values.

\section{Heritabilities and Repeatabilities}

Heritability estimates calculated from the univariate analysis are shown in Table 2. The milk fat and protein percentages had heritabilities of 0.370 and 0.364, respectively. Miglior et al. (2007) reported for Canadian Holstein cattle heritabilities ranging from 0.533 to 0.555 for fat percentage and 0.561 to 0.586 for protein percentage. These heritabilities are greater than those found in the current study, but when the standard errors are considered, the heritabilities are only slightly lower than expected. The observed differences are attributable to different population and

Table 1. Descriptive statistics of milk fat globule volume moment mean $(\mathrm{D}[4,3])$, surface moment mean $(\mathrm{D}[3,2])$, predicted volume moment mean $(\mathrm{pD}[4,3])$, predicted surface moment mean $(\mathrm{pD}[3,2])$, and milk fat and protein percentages

\begin{tabular}{lccc}
\hline Trait & $\mathrm{N}$ & Mean & $\mathrm{SD}$ \\
\hline $\mathrm{D}[4,3](\mu \mathrm{m})$ & 1,583 & 4.130 & 0.483 \\
$\mathrm{D}[3,2](\mu \mathrm{m})$ & 1,586 & 3.468 & 0.339 \\
$\mathrm{pD}[4,3](\mu \mathrm{m})$ & 1,551 & 4.171 & 0.357 \\
$\mathrm{pD}[3,2](\mu \mathrm{m})$ & 1,549 & 3.489 & 0.243 \\
Fat $(\%)$ & 3,643 & 3.951 & 0.704 \\
Protein $(\%)$ & 3,643 & 3.282 & 0.357 \\
\hline
\end{tabular}


simple genetic models used in the present study. Moderate heritabilities of 0.364 and 0.466 were found for $\mathrm{D}[4,3]$ and $\mathrm{D}[3,2]$, respectively. This finding suggests that the genetics of the cow plays a significant role in determining the average size of the MFG that are formed and secreted in milk, and selection for this trait is possible. Limited studies have examined the heritability of average MFG size in milk. Hassaneyn (1965) reported a high heritability of 0.73 for MFG size using a half-sib method in German Friesian cows, which included the records of 233 cows from 21 different sires. However, the methodologies used in the determination of MFG size are out of date and dissimilar to those used presently. Regardless, this finding still supports the notion that MFG size is heritable in dairy cattle. The variation in MFG size observed by Couvreur et al. (2007) and Logan et al. (2014) for cows within a herd may thus be explained in part by genetic differences with or without other unaccounted for on-farm factors. Argov-Argaman et al. (2013) used the ratio of phospholipid to triacylglycerol as an indicator of MFG size and discovered a significant relationship between this ratio and diacyglycerol acyltransferase 1 (DGAT1) genotype. The DGAT1 gene is involved in the last step of the synthesis of triacylglycerol and has a major effect on milk fat content (Grisart et al., 2002) and polar lipid content (Argov-Argaman et al., 2013). The regulation of the overall size distribution of MFG within a milk sample and how the size of any one particular MFG is determined remains unclear. The process by which the mature size of an individual MFG is determined as lipid droplets are transported, coalesced, and secreted is perplexing and requires a comprehensive examination to see the role, if any, of specific genes. Although the results of the present study provide evidence that the average MFG size in a milk sample has a genetic component, the complete genetic architecture of MFG size requires further investigation.

Repeatability estimates were similar for all examined traits (Table 2). Repeatabilities of 0.519 and 0.546 were

Table 2. Estimated heritabilities $\left(\mathrm{h}^{2}\right)$, their associated standard errors (SE), and repeatabilities (Rep) of milk fat globule volume moment mean $(\mathrm{D}[4,3])$, surface moment mean $(\mathrm{D}[3,2])$, predicted volume moment mean $(\mathrm{pD}[4,3])$, predicted surface moment mean $(\mathrm{pD}[3,2])$, and milk fat and protein percentages

\begin{tabular}{lccc}
\hline Trait & $\mathrm{h}^{2}$ & $\mathrm{SE}$ & $\mathrm{Rep}$ \\
\hline $\mathrm{D}[4,3]$ & 0.364 & 0.165 & 0.519 \\
$\mathrm{D}[3,2]$ & 0.466 & 0.163 & 0.546 \\
$\mathrm{pD}[4,3]$ & 0.300 & 0.172 & 0.500 \\
$\mathrm{pD}[3,2]$ & 0.239 & 0.172 & 0.495 \\
Fat $(\%)$ & 0.370 & 0.136 & 0.370 \\
Protein (\%) & 0.364 & 0.144 & 0.449 \\
\hline
\end{tabular}

estimated for $\mathrm{D}[4,3]$ and $\mathrm{D}[3,2]$, respectively. Slightly lower and closer to each other repeatabilities were found for $\mathrm{pD}[4,3](0.500)$ and $\mathrm{pD}[3,2](0.495)$. Genetic evaluation of MFG size would therefore benefit from multiple measurements throughout the lactating lifetime of a cow. Because predicted MFG size is coming from the MIR spectra captured during routine DHI milk recording, this trait would be available for every test-date, multiple times during the lactation.

The heritabilities of the predicted MFG size traits were both less than those found for their corresponding gold standard measured trait (0.300 and 0.239 for $\mathrm{pD}[4,3]$ and $\mathrm{pD}[3,2]$, respectively). The decrease in heritability was more marked between $\mathrm{D}[3,2]$ and $\mathrm{pD}[3,2]$ than between $\mathrm{D}[4,3]$ and $\mathrm{pD}[4,3]$. It is conceivable that more error is introduced into the predicted trait due to the poor performance of the MIR calibration model in the tails of the MFG size distributions, thereby resulting in lower heritabilities. The additive, residual, and phenotypic variance components associated with predicted MFG size were lower than the same components for measured MFG size (Table 3). This finding is attributable to a loss in the total phenotypic variability in the predicted values caused by the prediction models. The relative decline was greater for the additive genetic variance component compared with the permanent environment and residual components, resulting in the reduced heritability estimates. Cecchinato et al. (2009) observed the opposite for measured and MIR-predicted rennet coagulation time and curd firmness, finding that MIR predicted heritabilities were greater than the heritabilities estimated for their measured counterparts. A larger sample size would be required to properly evaluate whether true differences are present in the heritabilities of measured and predicted MFG size.

\section{Genetic Correlations}

Genetic correlations between the examined traits are shown in Table 4. A very strong genetic correlation

Table 3. Estimated additive genetic $\left(\sigma_{a}^{2}\right)$, permanent environment $\left(\sigma_{p e}^{2}\right)$, residual $\left(\sigma_{e}^{2}\right)$, and total phenotypic $\left(\sigma_{P}^{2}\right)$ variance of milk fat globule volume moment mean $(\mathrm{D}[4,3])$, surface moment mean $(\mathrm{D}[3,2])$, predicted volume moment mean $(\mathrm{pD}[4,3])$, predicted surface moment mean $(\mathrm{pD}[3,2])$, and milk fat and protein percentages

\begin{tabular}{lcccc}
\hline Trait & $\sigma_{a}^{2}$ & $\sigma_{p e}^{2}$ & $\sigma_{e}^{2}$ & $\sigma_{P}^{2}$ \\
\hline $\mathrm{D}[4,3]$ & 0.068 & 0.029 & 0.089 & 0.186 \\
$\mathrm{D}[3,2]$ & 0.044 & 0.008 & 0.043 & 0.094 \\
$\mathrm{pD}[4,3]$ & 0.028 & 0.019 & 0.047 & 0.095 \\
$\mathrm{pD}[3,2]$ & 0.011 & 0.012 & 0.023 & 0.046 \\
Fat $(\%)$ & 0.152 & 0.000 & 0.258 & 0.409 \\
Protein $(\%)$ & 0.025 & 0.006 & 0.038 & 0.070 \\
\hline
\end{tabular}


Table 4. Genetic correlations (SE in parentheses) of milk fat globule volume moment mean (D[4,3]), surface moment mean $(\mathrm{D}[3,2])$, predicted volume moment mean $(\mathrm{pD}[4,3])$, predicted surface moment mean $(\mathrm{pD}[3,2])$, and milk fat and protein percentages

\begin{tabular}{lccccc}
\hline Trait & $\mathrm{D}[3,2]$ & $\mathrm{pD}[4,3]$ & $\mathrm{pD}[3,2]$ & Fat $(\%)$ & Protein $(\%)$ \\
\hline $\mathrm{D}[4,3]$ & $0.980(0.022)$ & $0.685(0.209)$ & $0.626(0.253)$ & $0.538(0.217)$ & $0.335(0.297)$ \\
$\mathrm{D}[3,2]$ & & $0.798(0.161)$ & $0.764(0.171)$ & $0.681(0.153)$ & $0.524(0.277)$ \\
$\mathrm{pD}[4,3]$ & & & $0.985(0.027)$ & $0.976(0.159)$ & $0.760(0.318)$ \\
$\mathrm{pD}[3,2]$ & & & & $0.983(0.138)$ & $0.734(0.352)$ \\
\hline
\end{tabular}

(0.980) was found between $\mathrm{D}[4,3]$ and $\mathrm{D}[3,2]$. These 2 measures of average MFG size are heavily related because they are calculated from the same distribution, but they are biased in different directions. The surface moment mean $(\mathrm{D}[3,2])$ is more sensitive to the presence of small MFG, while $\mathrm{D}[4,3]$ is more sensitive to large particles in the globule size distribution. Therefore, a genetic correlation close to 1 was expected. The genetic correlation between $\mathrm{D}[4,3]$ and fat percentage was 0.538 , while the genetic correlation between $\mathrm{D}[3,2]$ and fat percentage was 0.681 . These genetic correlations may be explained in part by the relationship between MFG size and the DGAT1 genotype found by ArgovArgaman et al. (2013) because DGAT1 has a known effect on milk fat production. A significant phenotypic relationship between average MFG size and milk fat percentage was previously described for this population by Fleming et al. (2017), in which Pearson correlation coefficients of 0.34 and 0.36 were reported for $\mathrm{D}[4,3]$ and $\mathrm{D}[3,2]$, respectively. A phenotypic relationship between fat production and MFG size has also been noted by Wiking et al. (2004) in Danish Holstein cows. The genetic correlations for $\mathrm{D}[4,3]$ and $\mathrm{D}[3,2]$ with protein percentage were 0.335 and 0.524 , respectively.

A strong genetic correlation (0.685) between measured $\mathrm{D}[4,3]$ and its predicted equivalent, $\mathrm{pD}[4,3]$, was found. The genetic correlation between $\mathrm{D}[3,2]$ and $\mathrm{pD}[3,2]$ was marginally higher at 0.764 . The greater genetic correlation for $\mathrm{D}[3,2]$ measures may be due to the slightly greater $\mathrm{R}_{\mathrm{cv}}^{2}$ of the predictive model compared with that for $\mathrm{D}[4,3]$. Cecchinato et al. (2009) presented genetic correlations ranging from 0.71 to 0.87 between measured and MIR predicted curd firmness with prediction $\mathrm{R}^{2}$ values of 0.46 to 0.52 , and from 0.91 to 0.96 between measured and predicted rennet coagulation time with prediction $\mathrm{R}^{2}$ values of 0.61 to 0.69 . They concluded that using these MIR predictions as indicator traits would have equal to slightly lower response to selection compared with direct measurement. Although the MIR prediction equations used for MFG size are not precise enough to accurately quantify MFG size in a milk sample, the strong genetic correlation suggests that selecting animals based on the predicted values could still have realized effects on true MFG size.

The critical barrier to using the MIR predicted MFG size for selection is revealed in the genetic correlation with fat percentage. The correlation of fat percentage with $\mathrm{pD}[4,3]$ and with $\mathrm{pD}[3,2]$ were 0.976 and 0.983 , respectively, which is notably greater than what was observed for $\mathrm{D}[4,3]$ and $\mathrm{D}[3,2]$ (Table 4). The increase in the genetic correlation between fat percentage and the predicted MFG size phenotypes is likely an outcome of the prediction equation. Fat content is dominant in the milk MIR spectra, and because a seemingly weak relationship exists between the spectra and average MFG size, the prediction equation is utilizing the indirect correlation with fat content. Eskildsen et al. (2014) advised that phenotypic MIR predictions of individual fatty acids may be very much connected to total fat, and thus if the correlation between fatty acid contents and total fat is inconsistent, the prediction of future samples may be less accurate. This lower accuracy may be exceedingly true for the MFG size MIR predictions. The same phenomenon is again seen, but to a lesser extent, with protein percentage. The genetic correlation with protein percentage increased to 0.760 with $\mathrm{pD}[4,3]$ and 0.734 with $\mathrm{pD}[3,2]$. Protein is also a significant component of the milk MIR spectrum, and the phenotypic correlation may be augmented through the prediction equation. Therefore, despite the strong genetic correlation between the measured and predicted MFG size, the predicted values are more genetically associated with fat percentage, and selection based on the predicted MFG size values would be more so, putting selection pressure on fat percentage. Additional work can be done with a larger population having predicted MFG size to determine more precisely the genetic correlation between the predicted values and milk production traits.

Because of the small number of cows and limited samples, large standard errors are associated with most of the estimated genetic parameters, making definitive conclusions difficult. Before the real benefit of a MIR-predicted trait in genetic evaluations can be completely understood, it is important to have knowledge 
of the similarity of the genetic relationships between measured values, predicted values, and other correlated traits of interest. A comparison of the genetic parameters for gold standard measured traits and their MIRpredicted equivalents could frequently be restricted by a limited number of gold standard measured records. This limitation may result in genetic parameter estimates with large standard errors, but differences may still be distinguished and tendencies noted. The relationship of measured and predicted traits along with other milk components could reveal additional details of the information used by the prediction models. This information is also important to know if selection based on predicted traits would yield different results in correlated traits than their true values.

\section{CONCLUSIONS}

Milk fat globule size is a moderately heritable trait, and it may therefore be possible to alter the average size through selection. Genetic evaluation of this trait is limited by MFG size being arduous to phenotype as part of a milk recording program. Mid-infrared-predicted MFG size, which can be obtained during routine milk recording, could be used as an indicator trait in genetic selection because of the high genetic correlation between measured and MIR predicted average MFG size. However, the very strong genetic correlation that appears between predicted MFG size and fat percentage, which was not as strong between measured MFG size and fat percentage, indicates that MIR-predicted MFG size has little utility in selection programs.

\section{ACKNOWLEDGMENTS}

All dairy producers participating to this project are gratefully acknowledged. We warmly acknowledge Ian Rumbles (now at DRPC, Raleigh, NC) and all the CanWest DHI team (Guelph, ON) and Daniel Lefebvre and the full team at Valacta (Ste-Anne-de-Bellevue, QC) for kindly organizing the selection of herds and collecting samples for the project. This study was partly funded by the DairyGen Council of Canadian Dairy Network (Guelph, Ontario, Canada) and the Natural Sciences and Engineering Research Council of Canada (Ottawa, Ontario, Canada). This project is also supported by a contribution from the Dairy Research Cluster Initiative (Dairy Farmers of Canada, Agriculture and Agri-Food Canada, the Canadian Dairy Network, and the Canadian Dairy Commission). We warmly acknowledge FOSS (Hillerød, Denmark) for partial funding and technical support.

\section{REFERENCES}

Argov-Argaman, N., K. Mida, B.-C. Cohen, M. Visker, and K. Hettinga. 2013. Milk fat content and DGAT1 genotype determine lipid composition of the milk fat globule membrane. PLoS One 8:e68707.

Bonfatti, V., G. Di Martino, and P. Carnier. 2011. Effectiveness of mid-infrared spectroscopy for the prediction of detailed protein composition and contents of protein genetic variants of individual milk of Simmental cows. J. Dairy Sci. 94:5776-5785.

Carroll, S. M., E. J. DePeters, S. J. Taylor, M. Rosenberg, H. Perez-Monti, and V. A. Capps. 2006. Milk composition of Holstein, Jersey, and Brown Swiss cows in response to increasing levels of dietary fat. Anim. Feed Sci. Technol. 131:451-473.

Cecchinato, A., M. De Marchi, L. Gallo, G. Bittante, and P. Carnier. 2009. Mid-infrared spectroscopy prediction as indicator traits in breeding programs for enhanced coagulation properties of milk. J. Dairy Sci. 92:5304-5313.

Couvreur, S., C. Hurtaud, P. G. Marnet, P. Faverdin, and J. L. Peyraud. 2007. Composition of milk fat from cows selected for milk fat globule size and offered either fresh pasture or a corn silage-based diet. J. Dairy Sci. 90:392-403.

Eskildsen, C. E., M. A. Rasmussen, S. B. Engelsen, L. B. Larsen, N. A. Oulsen, and T. Skov. 2014. Quantification of individual fatty acids in bovine milk by infrared spectroscopy and chemometrics: Understanding predictions of highly collinear reference variables. J. Dairy Sci. 97:7940-7951.

Fleming, A., F. S. Schenkel, J. Chen, F. Malchiodi, R. A. Ali, B. Mallard, M. Sargolzaei, M. Corredig, and F. Miglior. 2017. Variation in fat globule size in bovine milk and its prediction using midinfrared spectroscopy. J. Dairy Sci. 100:1640-1649.

Grisart, B., W. Coppieters, F. Farnir, L. Karim, C. Ford, P. Berzi, N. Cambisano, M. Mni, S. Reid, P. Simon, R. Spelman, M. Georges, and R. Snell. 2002. Positional candidate cloning of a QTL in dairy cattle: Identification of a missense mutation in the bovine DGAT1 gene with major effect on milk yield and composition. Genome Res. 12:222-231.

Hassaneyn, A. 1965. Untersuchungen über die beziehungen der Fettkügelchengroße zur Milch- und Fettmenge und zum Fett- und Eiweißgehalt der Milch beim deutschen schwarzbunten Rind. Z. Tierz. Züchtungsbio. 81:216-230.

Hernell, O., N. Timby, M. Domellöf, and B. Lönnerdal. 2016. Clinical benefits of milk fat globule membranes for infants and children. J. Pediatr. 173:S60-S65.

Huppertz, T., and A. L. Kelly. 2006. Physical chemistry of milk fat globules. Pages 173-212 in Advanced Dairy Chemistry. Vol. 2: Lipids. 3rd ed. P. F. Fox and P. L. H. McSweeney, ed. Springer, New York, NY.

Keenan, T. W., and D. P. Dylewski. 1995. Intracellular origin of milk lipid globules and the nature and structure of the milk lipid globule membrane. Pages 89-130 in Advanced Dairy Chemistry. Vol. 2: Lipids. 2nd ed. P. F. Fox, ed. Chapman and Hall, London, UK.

Logan, A., M. Auldist, J. Greenwood, and L. Day. 2014. Natural variation of bovine milk fat globule size within a herd. J. Dairy Sci. 97:4072-4082.

Madsen, P., and J. Jensen. 2008. A User's Guide to DMU. A Package for Analyzing Multivariate Mixed Models. Version 6, release 5.1. Danish Institute of Agricultural Sciences, Tjele, Denmark.

Martini, M., F. Salari, and I. Altomonte. 2016. The macrostructure of milk lipids: The fat globules. Crit. Rev. Food Sci. Nutr. 56:12091221.

Mather, I. H., and T. W. Keenan. 1998. Origin and secretion of milk lipids. J. Mammary Gland Biol. Neoplasia 3:259-273.

McParland, S., E. Lewis, E. Kennedy, S. G. Moore, B. McCarthy, M. O'Donocan, S. T. Butler, J. E. Pryce, and D. P. Berry. 2014. Mid-infrared spectrometry of milk as a predictor of energy intake and efficiency in lactating dairy cows. J. Dairy Sci. 97:5863-5871.

Michalski, M. C., J. Y. Gassi, M. H. Famelart, N. Leconte, B. Camier, F. Michel, and V. Briard. 2003. The size of native milk fat glob- 
ules affects physico-chemical and sensory properties of Camembert cheese. Lait 83:131-143.

Miglior, F., A. Sewalem, J. Jamrozik, J. Bohmanova, D. M. Lefebvre, and R. K. Moore. 2007. Genetic analysis of milk urea nitrogen and lactose and their relationship with other production traits in Canadian Holstein cattle. J. Dairy Sci. 90:2468-2479.

Rutten, M. J. M., H. Bovenhuis, K. A. Hettinga, H. J. F. van Valenberg, and J. A. M. van Arendonk. 2009. Predicting bovine milk fat composition using infrared spectroscopy based on milk samples collected in winter and summer. J. Dairy Sci. 92:6202-6209.

Soyeurt, H., D. Bruwier, J.-M. Romnee, N. Gengler, C. Bertozzi, D. Veselko, and P. Dardenne. 2009. Potential estimation of major mineral contents in cow milk using mid-infrared spectrometry. J. Dairy Sci. 92:2444-2454.

Soyeurt, H., F. Dehareng, N. Gengler, S. McParland, E. Wall, D. P. Berry, M. Coffey, and P. Dardenne. 2011. Mid-infrared prediction of bovine milk fatty acids across multiple breeds, production systems, and countries. J. Dairy Sci. 94:1657-1667.
Spitsberg, V. L. 2005. Invited review: Bovine milk fat globule membrane as a potential nutraceutical. J. Dairy Sci. 88:2289-2294.

Stemberger, B. H., and S. Patton. 1981. Relationships of size, intracellular location, and time required for secretion of milk fat droplets. J. Dairy Sci. 64:422-426.

Walstra, P. 1969. Studies on milk fat dispersion II. The globule-size distribution of cow's milk. Neth. Milk Dairy J. 23:99-110.

Walstra, P. 1995. Physical Chemistry of Milk Fat Globules. Pages 131-178 in Advanced Dairy Chemistry. Vol. 2: Lipids. P. F. Fox, ed. Chapman and Hall, London, UK.

Wiking, L., L. Björck, and J. H. Nielsen. 2003. Influence of feed composition on stability of fat globules during pumping of raw milk. Int. Dairy J. 13:797-803

Wiking, L., J. Stagsted, L. Björck, and J. H. Nielsen. 2004. Milk fat globule size is affected by fat production in dairy cows. Int. Dairy J. 14:909-913. 